\title{
Decellularization of Human Umbilical Arteries
}

\author{
Descelularización de las Arterias Umbilicales Humanas
}

\author{
Víctor Emanuel Rodríguez-Rodríguez; ; Alejandro Quiroga-Garza ${ }^{1}$; Carlos Saúl Rodríguez-Roque²; \\ María de Jesús Loera-Arias²; Adolfo Soto-Domínguez²; Santos Guzmán-López; José Félix \\ Vilchez-Cavazos $^{3}$; Roberto Montes-de-Oca-Luna ${ }^{2} \&$ Rodrigo Enrique Elizondo-Omaña ${ }^{1}$
}

RODRÍGUEZ-RODRÍGUEZ, V. E.; QUIROGA-GARZA, A.; RODRÍGUEZ-ROQUE, C. S.; LOERA-ARIAS, M. J.; SOTODOMÍNGUEZ,A.; GUZMÁN-LÓPEZ, S.; VILCHEZ-CAVAZOS, J. F.; MONTES-DE-OCA-LUNA, R. \& ELIZONDO-OMAÑA, R. E. Decellularization of human umbilical arteries. Int. J. Morphol., 37(1):111-117, 2019.

SUMMARY: Arterial obstruction in small diameter $(<6 \mathrm{~mm})$ vessels are many times treated with grafts, however autologous aren't always available and synthetic have a high rate of complications. Decellularization of umbilical arteries may provide a solution, but the ideal method is debatable. We compare effectiveness between SDS and Triton X-100. Umbilical cords obtained from full term pregnancies with normal development and no evident complications in the newborn, were micro-dissected within $12 \mathrm{~h}$ and stored in phosphate buffered saline without freezing. Arteries were then processed for decellularization using $0.1 \%$ and $1 \%$ SDS, and $1 \%$ Triton X100 protocols. Evaluation of cellular and nuclear material, collagen fibers, elastic fibers, and glycosoaminoglycans of the extracellular matrix (ECM) were evaluated as well as morphometric analysis under histological and immunohistochemical techniques. Triton X-100 was ineffective, preserving nuclear remains identified by immunofluorescence, had the most notable damage to elastic fibers, and decrease in collagen. SDS effectively eliminated the nuclei and had a less decrease in elastic fibers and collagen. Laminin was preserved in all groups. No significant differences were identified in luminal diameters; however the middle layer decreased due to decellularization of muscle cells. In conclusion, $0.1 \%$ SDS decellularization was the most effective in eliminating cells and preserving the main components of the ECM.

KEY WORDS: Decellularization; Umbilical artery; Vascular graft; Extracellular matrix.

\section{INTRODUCTION}

Cardiovascular disease is the leading cause of mortality worldwide and it is estimated it this will continue up to the year 2030 (Mathers \& Loncar, 2006; World Health Organization, 2014). One of the main complications is arterial obstruction, causing ischemia distal to the blockage. In these cases, if it is a small diameter $(<6 \mathrm{~mm})$ vessel, it can be treated using autologous grafts. The saphenous vein and internal thoracic artery are the best options; however, these aren't always viable or available (Zdrahala, 1996; L'Heureux et al., 2007; Martínez-González et al., 2015). Vascular prosthesis from synthetic materials such as expanded tetrafluoroethylene (ePTFE) and Dacron have a limited use in small diameters due to high thrombosis formation (Yeh et al., 1984; Teebken et al., 2002; Zilla et al., 2007). Various substitutes have been developed for these cases, such as: Synthetic prostheses coated with endothelial cells, collagen vascular analogues, biodegradable polymer conduits, and decellularized blood vessels (Naito et al., 2011).
Decellularization is a process in which cellular and nuclear material is removed, minimizing damage to the extracellular matrix (ECM), allowing them to conserve certain characteristics and advantages that make them more favorable for grafting (Gilbert et al., 2006). Their three-dimensional structure is preserved, there is little or no immunological reaction, and their biomechanical properties allow them greater functionality and adaptation than vascular prostheses (Schaner et al., 2004; Roy et al., 2005; Gui et al., 2009). However, the selection of ideal blood vessels for this method is debated.

The umbilical vessels are an adequate potential source because they are, easy to obtain, have a suitable diameter, and lack branches (Hoenicka et al., 2007; Gui et al., 2009; Vázquez Blanco et al., 2011). Each umbilical cord has two arteries and one umbilical vein surrounded by Wharton's jelly. Umbilical arteries have been morphologically studied with the intent

\footnotetext{
${ }^{1}$ Universidad Autónoma de Nuevo Leon, Facultad de Medicina, Human Anatomy Department, México.

${ }^{2}$ Universidad Autónoma de Nuevo Leon, Facultad de Medicina, Histology Department, México.

${ }^{3}$ Universidad Autónoma de Nuevo Leon, Facultad de Medicina and University Hospital "Dr. Jose Eleuterio Gonzalez", Bone and Tissue Preservation Bank, México.
} 
RODRÍGUEZ-RODRÍGUEZ, V. E.; QUIROGA-GARZA, A.; RODRÍGUEZ-ROQUE, C. S.; LOERA-ARIAS, M. J.; SOTO-DOMÍNGUEZ, A.; GUZMÁN-LÓPEZ, S.; VILCHEZ CAVAZOS, J. F.; MONTES-DE-OCA-LUNA, R. \& ELIZONDO-OMAÑA, R. E. Decellularization of human umbilical arteries. Int. J. Morphol., 37(1):111-117, 2019.

for microvascular reconstruction (Yeh et al.), and recently with decellularization for vascular grafting. However, there is no agreement on which is the best decellularization technique (Rodríguez-Rodríguez et al., 2018). The two most effective detergents used for this purpose are sodium dodecyl sulfate (SDS) and Triton X-100. Both have been reported to effectively decellularize umbilical vessels [SDS on arteries (Rodriguez et al., 2012; Mallis et al., 2014; Tuan-Mu et al., 2014) and Triton X-100 on veins (Uzarski et al., 2013; Goktas et al., 2014)], however results vary, and the data are limited. Therefore, the objective of this study was to compare the effectiveness of decellularization with SDS vs Triton X-100 in umbilical arteries to establish which one has greater potential.

\section{MATERIAL AND METHOD}

Ethical aspects. The study was evaluated and approved by the ethics and research committee of the Medical School and University Hospital "Dr. José Eleuterio González" with registration number AH15-006.

Preparation of the umbilical arteries. Seven umbilical cords were obtained anonymously from the obstetrics division in the University Hospital "Dr. José Eleuterio González" (Monterrey, Mexico). Inclusion criteria were: normal morphology of the cord from full-term pregnancies with normal evolution and no evident complication of the newborn or birth (method of birth was not a criterion).

The umbilical cords were stored immediately in $1 \mathrm{X}$ phosphate buffered saline (PBS) with a pH of 7.4 in sealed containers. These were then transported to the micro-surgery laboratory where the two umbilical arteries were obtained with manual micro-dissection under a sterile technique in less than $12 \mathrm{~h}$ from obtaining the umbilical cord. The mean length of the arteries was $\sim 20-25 \mathrm{~cm}$, dividing these into four segments of approximately $\sim 5 \mathrm{~cm}$, of which, three were stored in PBS for immediate decellularization processing, and the remaining segment was fixed in $4 \%$ paraformaldehyde (PFA) and stored at $4{ }^{\circ} \mathrm{C}$ to be used as a control.

Decellularization of the umbilical arteries. After a detailed review of the literature regarding decellularization techniques, we decided to use $0.1 \%$ and $1 \%$ SDS, and $1 \%$ Triton X-100 (Rodríguez-Rodríguez et al.).

SDS decellularization consisted of immersing the arteries in $50 \mathrm{ml}$ falcon tubes with hypotonic buffer $(10 \mathrm{mM}$ tris, $\mathrm{pH} 8.0$ ) at $4{ }^{\circ} \mathrm{C}$ for $24 \mathrm{~h}$ and then a cycle in hypotonic buffer ( $\mathrm{pH} 7.4$ ) with $0.1 \%$ or $1 \%$ of SDS at $37^{\circ} \mathrm{C}$ for $24 \mathrm{~h}$, with constant agitation and presence of protease inhibitors of Aprotinin, $\left(10 \mathrm{KIU} * \mathrm{~mL}^{-1}\right)$ (Abcam, Cambridge, MA, USA) and $0.1 \%$ of EDTA as protease inhibitors. The segments were then washed three times for $30 \mathrm{~min}$ in PBS. The process continued with incubation in DNase $\left(50 \mathrm{U}^{*} \mathrm{~mL}^{-}\right.$ $\left.{ }^{1}\right)$ (Abcam, Cambridge, MA, USA) and RNase $\left(1 \mathrm{U} * \mathrm{~mL}^{-1}\right)$ (Abcam, Cambridge, MA, USA) in a buffer (50 mM tris-HCL, $10 \mathrm{mM} \mathrm{MgCl} 2,50$ micrograms $* \mathrm{~mL}^{-1}$ bovine serum albumin, $\mathrm{pH}$ of 7.6) for $3 \mathrm{~h}$ at $37^{\circ} \mathrm{C}$. Afterwards, each segment was immersed in a hypertonic buffer $(1.5 \mathrm{M} \mathrm{NaCl}$ in $0.05 \mathrm{M}$ tris$\mathrm{HCL}, \mathrm{pH}$ 7.6) for $24 \mathrm{~h}$ at $37^{\circ} \mathrm{C}$. Finally, the arteries were washed three times in PBS at $4{ }^{\circ} \mathrm{C}$ for $30 \mathrm{~min}$, under constant agitation, followed by two 24-hour washes.

Triton X-100 decellularization was performed by immersing the arteries in PBS under constant agitation with $1 \%$ triton X-100 for $24 \mathrm{~h}$. After the arteries were washed three times with PBS for 30 min and subsequently incubated in DNase $\left(50 \mathrm{U}^{*} \mathrm{~mL}^{-1}\right)$ and RNase $\left(1 \mathrm{U}^{*} \mathrm{~mL}^{-1}\right)$ in a buffer (50 mM tris-HCL, $10 \mathrm{mM} \mathrm{MgCl} 2,50$ micrograms $* \mathrm{~mL}^{-1}$ of bovine serum albumin, at a $\mathrm{pH}$ of 7.6 ) for $3 \mathrm{~h}$ at $37^{\circ} \mathrm{C}$. They were washed three times in PBS at $4{ }^{\circ} \mathrm{C}$ for $30 \mathrm{~min}$, in constant agitation and finally two 24-hour washes.

After decellularization, the arteries were stored in 4 $\%$ PFA for subsequent conventional histological technique processing and inclusion in paraffin blocks.

Determination of decellularization. Arterial segments from the control and decellularized groups underwent histological technique and sliced at $5 \mathrm{~mm}$. Slices were stained with hematoxylin and eosin (H\&E) to assess the removal of the cellularity and nuclear material. The components of the ECM were analyzed using: Masson trichrome for the evaluation of the collagen fibers, Orcein/trichrome of Van Gieson for elastic and collagen fibers, and histochemistry with periodic acid Shiff (PAS) to identify polysaccharides such as glycosaminoglycans complex (GAGs) and proteoglycans. Immunofluorescence staining was also performed with DAPI (Abcam, Cambridge, MA, USA) to analyze the presence of nuclear remnants. Type I and IV collagen, and laminin were also analyzed (Camara Q capture with micropublisher 5.0 RTV software) using rabbit specific monoclonal antibodies (Abcam, Cambridge, MA, USA) at titers of 1:50, 1:50, and 1:20, respectively for immunohistochemistry.

Morphometric analysis. H\&E stained slices were measured for luminal diameters and middle layer thickness at a $4 \mathrm{X}$ magnification, using the QCapture Pro software (version 6.0). Five measurements were made in different place of the slice, measuring from end to end excluding the adventitia.

Statistical Analysis. The results of the morphological evaluation with optical and fluorescence microscopy were 
RODRÍGUEZ-RODRÍGUEZ, V. E.; QUIROGA-GARZA, A.; RODRÍGUEZ-ROQUE, C. S.; LOERA-ARIAS, M. J.; SOTO-DOMÍNGUEZ, A.; GUZMÁN-LÓPEZ, S.; VILCHEZCAVAZOS, J. F.; MONTES-DE-OCA-LUNA, R. \& ELIZONDO-OMANA, R. E. Decellularization of human umbilical arteries. Int. J. Morphol., 37(1):111-117, 2019.

evaluated in a quantitative manner by two observers. For the morphometries, the mean value of the five measurements was taken and the Kolmogorov-Smirnoff was performed to determine normality. Based on this, we decided to use the T Student test for differences taking as significant a value of $\mathrm{p}<0.05$.

\section{RESULTS}

Morphological analysis. The control umbilical arteries were stained to evaluate the presence of cellular and nuclear material, collagen fibers, elastic fibers and GAGs of the ECM (Fig. 1). H\&E staining was applied to decellularized arteries with $0.1 \%$ SDS, 1 $\%$ SDS, and $1 \%$ Triton X-100, observing empty spaces were cellular and nuclear material used to be. There seemed to be an absence of cells, however, nuclear remains were identified using DAPI immunofluorescence in Triton X-100 arteries (Fig. 2).

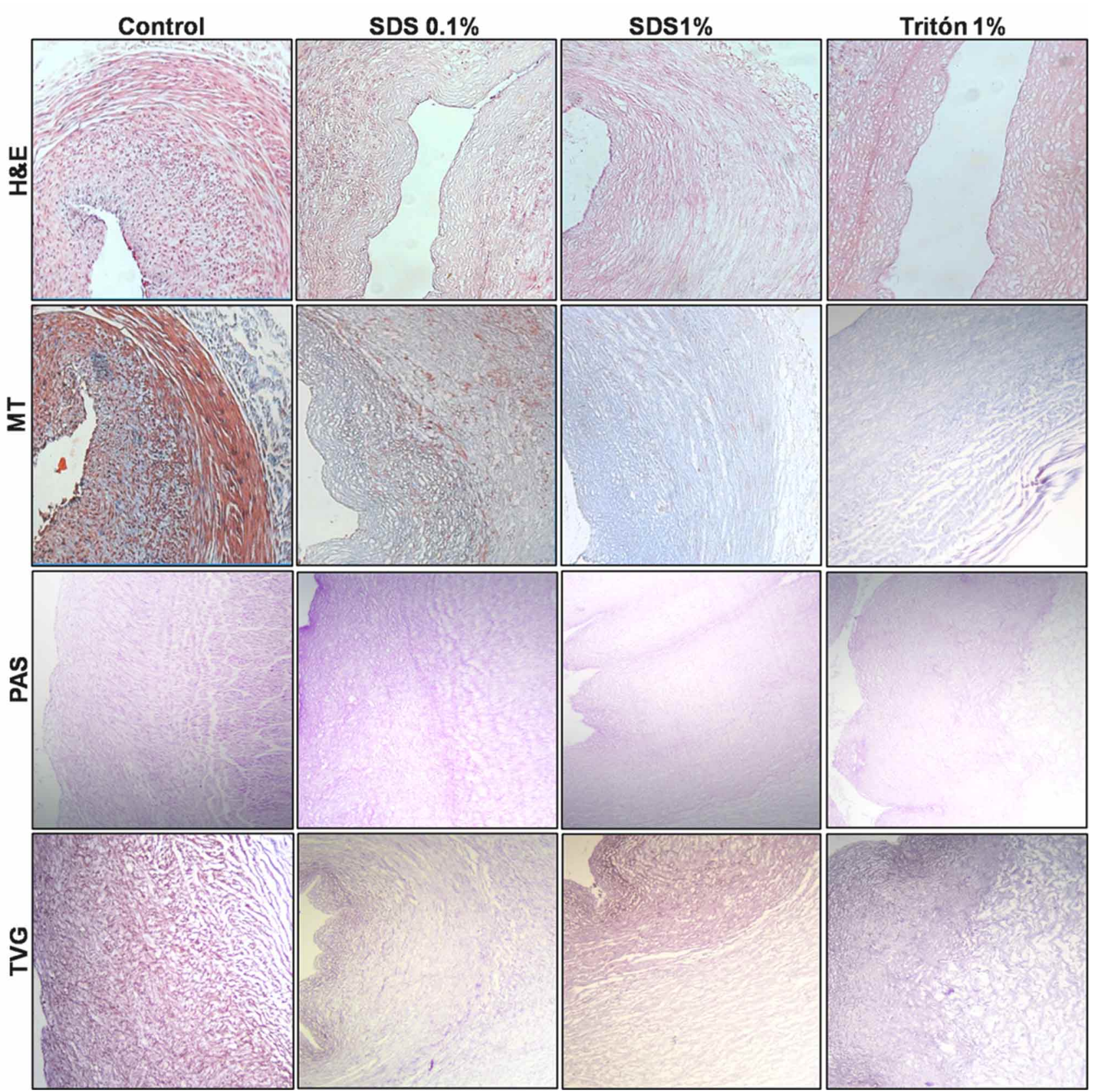

Fig. 1. Histological staining techniques in control and decellularization groups. Histological techniques are divided by rows. The umbilical arteries are stained with Hematoxylin and eosin stain (H\&E), Masson trichrome (MT)(collagen is stained blue), Orcein/trichrome of Van Gieson (TVG), and histochemistry with periodic acid Shiff (PAS, glycosaminoglycans complex are stained pink). Groups are divided by columns as control, sodium dodecyl sulfate (SDS) $0.1 \%$, SDS $1 \%$, and Tritón X-100 $1 \%$. Light microscopy at 10x power. 
RODRÍGUEZ-RODRÍGUEZ, V. E.; QUIROGA-GARZA, A.; RODRÍGUEZ-ROQUE, C. S.; LOERA-ARIAS, M. J.; SOTO-DOMÍNGUEZ, A.; GUZMÁN-LÓPEZ, S.; VILCHEZCAVAZOS, J. F.; MONTES-DE-OCA-LUNA, R. \& ELIZONDO-OMAÑA, R. E. Decellularization of human umbilical arteries. Int. J. Morphol., 37(1):111-117, 2019.

The Masson's Trichrome stain showed the collagen of the ECM is conserved in umbilical arteries after decellularization, with a more attenuated stain appreciated in Triton X-100 (Fig. 1). When type I and type IV collagen were immunohistochemically analyzed, their presence was confirmed, with a notable involvement in Triton X-100 (Fig. 3). Laminin was also conserved in all groups (Fig. 3).

The presence of elastic fibers was evaluated with the Orcein/trichrome stain of Van Gieson. Decellularizaed arteries demonstrated a decrease of elastic fibers most notably in Triton X-100 (Fig. 1). Similar results were found when evaluating GAGs (Fig. 1).

Morphometric analysis. The luminal diameters of the umbilical arteries showed no significant differences between groups. However, a significant decrease in the thickness of the middle layer was identified after decellularization (Table I).

\section{Control}

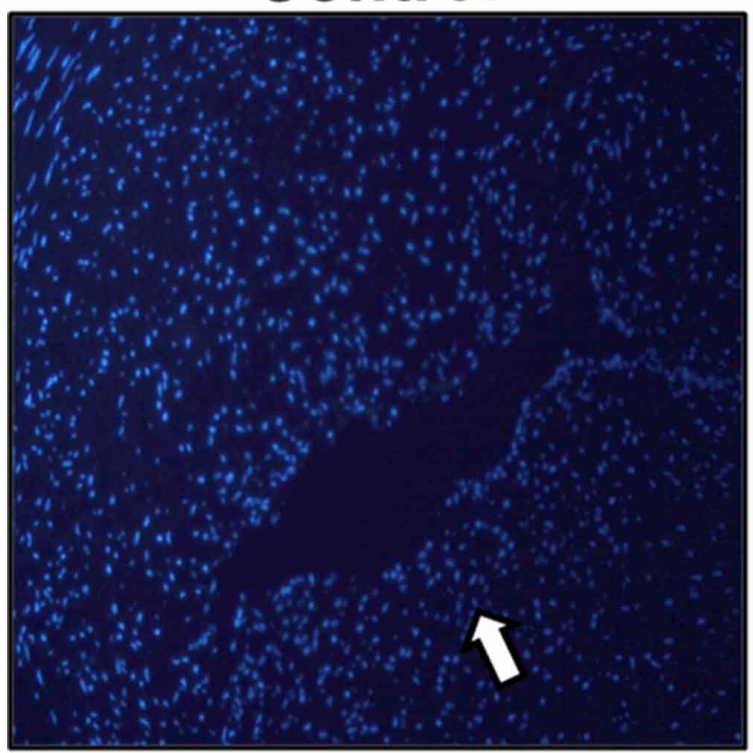

SDS $1 \%$

\section{SDS $0.1 \%$}

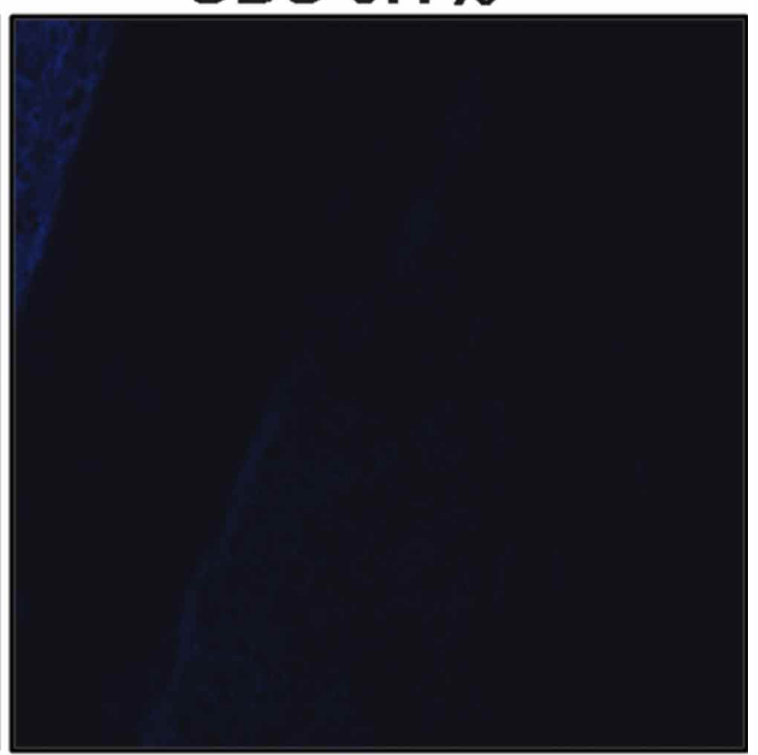

Triton $1 \%$
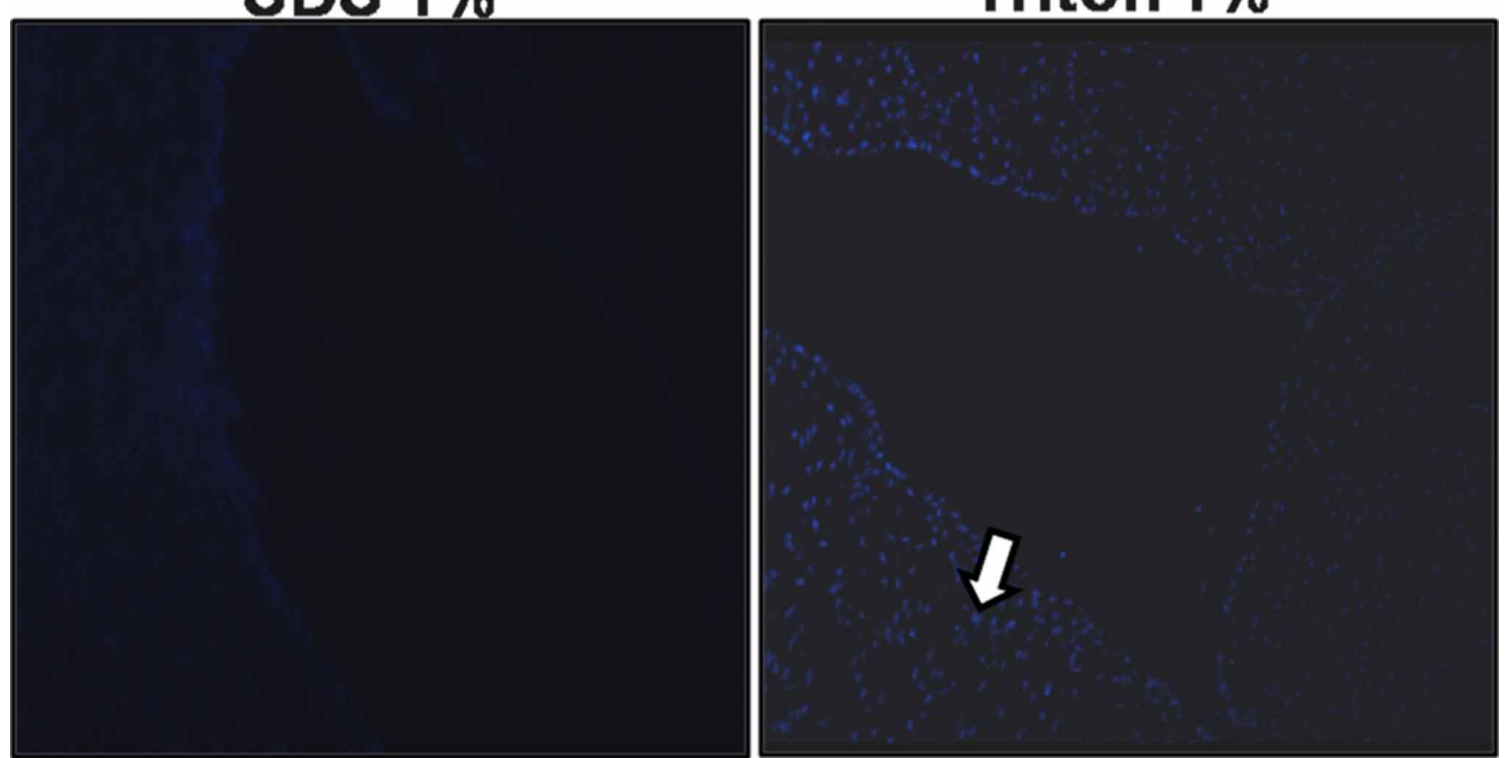

Fig. 2. Immunofluorescence staining with DAPI in control and decellularization groups. DAPI immunofluorescence staining (nuclear remnants are stained bright blue). Fluorescence microscopy at 10x power. White arrows show nucleus or nuclear remnants. 


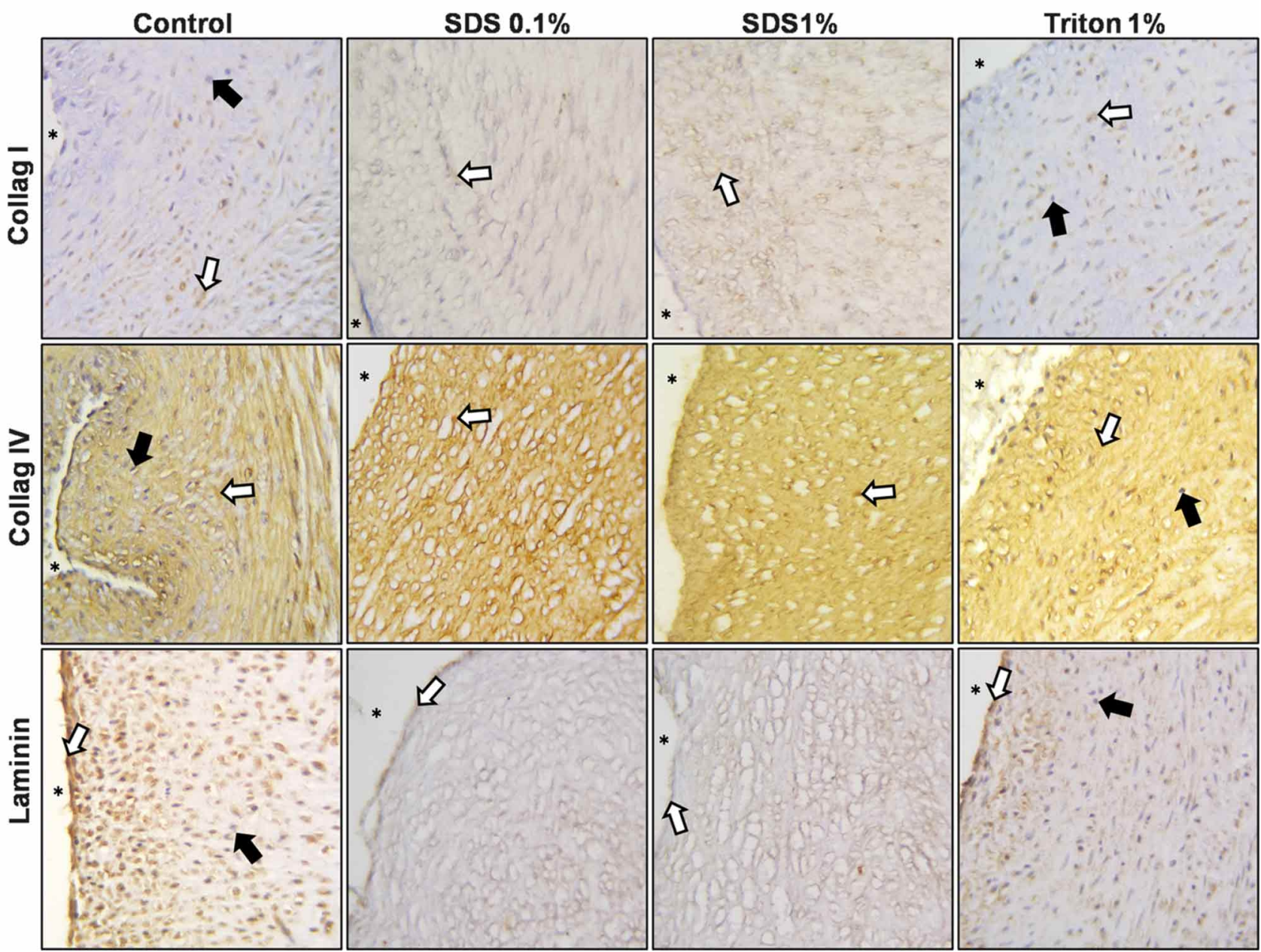

Fig. 3. Immunohistochemistry in control and decellularization groups. Immunohistochemistry for type I collagen (collag I), type IV collagen (collag IV) and laminin. Groups are divided by columns as control, sodium dodecyl sulfate $0.1 \%$ (SDS), SDS $1 \%$, and Tritón X-100 $1 \%$. Light microscopy at 40x power. White arrows show positivity; black arrows show nucleus or nuclear remnants; * indicates the arterial lumen.

Table I. Morphometrics of umbilical arteries in control and decellularization groups.

\begin{tabular}{|c|c|c|c|c|c|c|c|}
\hline P arameter & Control & SDS $0.1 \%$ & $\mathrm{p}$ & SDS $1 \%$ & $\mathrm{p}$ & Triton $1 \%$ & $\mathrm{p}$ \\
\hline & 1 & 1.8 & 0 & 1. & 0.78 & 0.14 & 0. \\
\hline Thickness $\mathrm{M} \pm \mathrm{SD}(\mu \mathrm{m})$ & $827.9 \pm 48.14$ & $664.42 \pm 74.32$ & $0.012 *$ & $664.5 \pm 81.59$ & $0.015^{*}$ & $694.3 \pm 86.6$ & $0.02 *$ \\
\hline
\end{tabular}

M: Medium; SD: Standard deviation; $\mathrm{mm}$ : millimeters; mm: micrometers; *: statistically significant value ( $<<0.05)$.

\section{DISCUSSION}

In this study we examined the effectiveness of two methods to decellularize umbilical arteries. Decellularized umbilical arteries are a potential source of small diameter grafts due to their high availability and ease of isolation/ dissection; important advantages over other decellularized vessels (Schaner et al.; Borschel et al., 2005; Martin et al., 2005).
It is important to note the process of obtaining and storing the arteries. During dissection, you can alter the vessel wall, which can affect the biomechanical behavior (RodríguezRodríguez et al.). Care should be taken in this process to ensure high-quality arterial segments. The morphology and efficiency of decellularization can also be altered if arteries are frozen for storage and conservation (Tuan-Mu 
RODRÍGUEZ-RODRÍGUEZ, V. E.; QUIROGA-GARZA, A.; RODRÍGUEZ-ROQUE, C. S.; LOERA-ARIAS, M. J.; SOTO-DOMÍNGUEZ, A.; GUZMÁN-LÓPEZ, S.; VILCHEZCAVAZOS, J. F.; MONTES-DE-OCA-LUNA, R. \& ELIZONDO-OMAÑA, R. E. Decellularization of human umbilical arteries. Int. J. Morphol., 37(1):111-117, 2019.

et al.). Using cryoprotectants could help avoid this, as it has used with other human vessels (Lomas et al., 2013) however, studies with their use in umbilical arteries are needed.

The decellularization was effective, as we identified the nuclei were eliminated with both concentrations of SDS. This coincides with other studies where $1 \%$ SDS was used (Rodriguez et al.; Tuan-Mu et al.). However, $1 \%$ of Triton X-100 was ineffective, with nuclei still present after the process. It is important to mention the role of nucleases for an efficient decellularization, as shown in other studies (Gui et al., 2010; Mallis et al.).

We observed that some of the components of the ECM can be altered by the decellularization. Collagen, abundant in umbilical arteries, was qualitatively diminished by the processes, most noticeably in the Triton X-100 group. Previous studies also report the alteration on collagen fibers caused by $1 \%$ SDS (Mallis et al.). Type I collagen was preserved in decellularized arteries but with tendency to diminish when increasing the concentration of the detergent, and with greater intensity in the Tritón X-100 group. With collagen IV, a similar situation was identified. Previous studies report type I (Mallis et al.) and IV (Gui et al., 2009) collagen was not affected by SDS. More studies are needed to clearly define the magnitude of collagen damage.

Umbilical arteries do not have clearly defined internal or external elastic laminas. When decellularizing, the elastic fibers were diminished, with greater extent in Triton X-100. These findings are similar to those observed in another study that used SDS (Gui et al., 2009). However, the analysis was only qualitative. More specific studies are needed to clearly establish the level of damage.

GAG's are also abundant in umbilical arteries. These decreased when decellularized with any of the methods, but it was more evident with Triton $\mathrm{X}-100$. We did not find studies in the literature where these components were evaluated in the decellularized umbilical arteries, so it is necessary to analyze these components in an objective way to define their post-decellularization status.

Laminin was found preserved with $0.1 \%$ SDS. However, with $1 \%$ SDS and with triton X-100 it was not clearly appreciated. We did not find enough data to ensure its integrity after decellularization.

Biomechanical capabilities are a key feature of the decellularized vessels, and it has been described that the decellularized umbilical arteries have a similar mechanical behavior as to fresh arteries (Gui et al., 2009; Rodriguez et $a l$.). The state of the vascular wall after decellularization is a crucial factor in maintaining the mechanical profile. Regarding the morphometrics, there were no differences in diameter when comparing between groups. This seems to indicate that the three-dimensional structure is conserved, however, the thickness was found to be significantly reduced after decellularization, indicating a loss of the structure of the middle layer of the artery constituted by smooth muscle.

It is necessary to carry out biomechanical studies to analyze if these changes affect the behavior and the adaptation capacity of the vessel. Once confirmed, in vivo experimental studies in animal models (Velazquez-Gauna et al., 2017) are needed to evaluate the performance of the decellularized grafts. These including their mechanical properties, hemodynamics, and adaptation process for short and long term (Martin et al.). Vascular end-to-end anastomoses in a rat model would provide adequate diameter comparability, and a possible model to test these findings (Yeh et al.; Velazquez-Gauna et al.).

\section{CONCLUSION}

The decellularization protocol with $0.1 \%$ SDS was more effective than SDS at $1 \%$ and Triton X-100 at $1 \%$ regarding the elimination of cells and the preservation of the main components of the extracellular matrix.

RODRÍGUEZ-RODRÍGUEZ, V. E.; QUIROGA-GARZA, A.; RODRIGUEZ-ROQUE, C. S.; LOERA-ARIAS, M. J.; SOTODOMÍNGUEZ, A.; GUZMÁN-LÓPEZ, S.; VILCHEZCAVAZOS，J. F.; MONTES-DE-OCA-LUNA，R. \& ELIZONDO-OMAÑA, R. E. Descelularización de las arterias umbilicales humanas. Int. J. Morphol., 37(1):111-117, 2019.

RESUMEN: la obstrucción arterial en vasos de pequeño diámetro $(<6 \mathrm{~mm})$ se trata muchas veces con injertos, sin embargo, los autólogos no siempre están disponibles y los sintéticos tienen una alta tasa de complicaciones. La descelularización de las arterias umbilicales puede proporcionar una solución, pero el método ideal es discutible. Comparamos la efectividad entre los métodos SDS y Triton X-100. Cordones umbilicales obtenidos a partir de embarazos a término con evolución normal y sin complicaciones evidentes del recién nacido, se microdiseccionaron en 12 horas y se almacenaron en solución salina con fosfato sin congelación. Las arterias se procesaron luego para la descelularización usando los protocolos de SDS al 0,1\% y $1 \%$, y Triton X-100 al 1 $\%$. Se realizó la evaluación de material celular y nuclear, fibras de colágeno, fibras elásticas y glucosoaminoglicanos de la matriz extracelular (MEC), así como el análisis morfométrico bajo técnicas histológicas e inmunohistoquímicas. Triton X-100 fue ineficaz, conservando los restos nucleares identificados por inmunofluorescencia, tuvo el daño más notable a las fibras elásticas y la disminución del colágeno. SDS efectivamente eliminó los núcleos y tuvo una disminución menor en las fibras elásticas y el 
colágeno. Laminina fue preservado en todos los grupos. No se identificaron diferencias significativas en los diámetros luminales; sin embargo, la capa media disminuyó debido a la descelularización de las células musculares. la descelularización con SDS al 0,1\% fue la más efectiva para eliminar células y preservar los principales componentes de la MEC.

KEY WORDS: Decellularization; Umbilical artery; vascular graft; extracellular matrix

\section{REFERENCES}

Borschel, G. H.; Huang, Y. C.; Calve, S.; Arruda, E. M.; Lynch, J. B.; Dow, D. E.; Kuzon, W. M.; Dennis, R. G. \& Brown, D. L. Tissue engineering of recellularized small-diameter vascular grafts. Tissue Eng., 11(56): $778-86,2005$.

Gilbert, T. W.; Sellaro, T. L. \& Badylak, S. F. Decellularization of tissues and organs. Biomaterials, 27(19):3675-83, 2006

Goktas, S.; Matuska, A. M.; Pierre, N.; Gibson, T. M.; Dmytryk, J. J. \& McFetridge, P. S. Decellularization method influences early remodeling of an allogenic tissue scaffold. J. Biomed. Mater. Res. A, 102(1):8-16, 2014.

Gui, L.; Chan, S. A.; Breuer, C. K. \& Niklason, L. E. Novel utilization of serum in tissue decellularization. Tissue Eng. Part C Methods, 16(2):173-84, 2010.

Gui, L.; Muto, A.; Chan, S. A.; Breuer, C. K. \& Niklason, L. E. Development of decellularized human umbilical arteries as small-diameter vascular grafts. Tissue Eng. Part A, 15(9):2665-76, 2009.

Hoenicka, M.; Lehle, K.; Jacobs, V. R.; Schmid, F. X. \& Birnbaum, D. E. Properties of the human umbilical vein as a living scaffold for a tissueengineered vessel graft. Tissue Eng., 13(1):219-29, 2007.

L'Heureux, N.; Dusserre, N.; Marini, A.; Garrido, S.; de la Fuente, L. \& McAllister, T. Technology insight: the evolution of tissue-engineered vascular grafts--from research to clinical practice. Nat. Clin. Pract. Cardiovasc. Med., 4(7):389-95, 2007.

Lomas, R. J.; Dodd, P. D.; Rooney, P.; Pegg, D. E.; Hogg, P. A.; Eagle, M. E.; Bennett, K. E.; Clarkson, A. \& Kearney, J. N. A standardised protocol for the validation of banking methodologies for arterial allografts. Cell Tissue Bank, 14(3):495-503, 2013.

Mallis, P.; Gontika, I.; Poulogiannopoulos, T.; Zoidakis, J.; Vlahou, A.; Michalopoulos, E.; Chatzistamatiou, T.; Papassavas, A. \& StavropoulosGiokas, C. Evaluation of decellularization in umbilical cord artery, Transplant. Proc., 46(9):3232-9, 2014.

Martin, N. D.; Schaner, P. J.; Tulenko, T. N.; Shapiro, I. M.; Dimatteo, C. A.; Williams, T. K.; Hager, E. S. \& DiMuzio, P. J. In vivo behavior of decellularized vein allograft. J. Surg. Res., 129(1):17-23, 2005.

Martínez-González, B.; Theriot-Girón, M. C.; López-Serna, N.; MoralesAvalos, R.; Quiroga-Garza, A.; Reyes-Hernández, C. G.; VillanuevaOlivo, A.; Leyva-Villegas, J. I.; Soto-Domínguez, A.; de la FuenteVillarreal, D.; Elizondo-Omaña, R. E. \& Guzmán-López, S. Morphological analysis of major segments of coronary artery occlusion. Importance in myocardial revascularization surgery. Int. J. Morphol., 33(4):1205-12, 2015.

Mathers, C. D. \& Loncar, D. Projections of global mortality and burden of disease from 2002 to 2030. PLoS Med., 3(11):e442, 2006.

Naito, Y.; Shinoka, T.; Duncan, D.; Hibino, N.; Solomon, D.; Cleary, M.; Rathore, A.; Fein, C.; Church, S. \& Breuer, C. Vascular tissue engineering: towards the next generation vascular grafts. Adv. Drug Deliv. Rev., 63(4-5):312-23, 2011.

Rodríguez-Rodríguez, V. E.; Martínez-González, B.; Quiroga-Garza, A.; Reyes-Hernández, C. G.; de la Fuente-Villarreal, D.; de la Garza-Cas- tro, O.; Guzmán-López, S. \& Elizondo-Omaña, R. E. Human umbilical vessels: choosing the optimal decellularization method. ASAIO J., 64(5):575-80, 2018.

Rodriguez, M.; Juran, C.; McClendon, M.; Eyadiel, C. \& McFetridge, P. S. Development of a mechanically tuneable 3D scaffold for vascular reconstruction. J. Biomed. Mater. Res. A, 100(12):3480-9, 2012.

Roy, S.; Silacci, P. \& Stergiopulos, N. Biomechanical properties of decellularized porcine common carotid arteries. Am. J. Physiol. Heart Circ. Physiol., 289(4):H1567-76, 2005.

Schaner, P. J.; Martin, N. D.; Tulenko, T. N.; Shapiro, I. M.; Tarola, N. A.; Leichter, R. F.; Carabasi, R. A. \& Dimuzio, P. J. Decellularized vein as a potential scaffold for vascular tissue engineering. J. Vasc. Surg., 40(1):146-53, 2004.

Teebken, O. E. \& Haverich, A. Tissue engineering of small diameter vascular grafts. Eur. J. Vasc. Endovasc. Surg., 23(6):475-85, 2002.

Tuan-Mu, H. Y.; Yu, C. H. \& Hu, J. J. On the decellularization of fresh or frozen human umbilical arteries: implications for small-diameter tissue engineered vascular grafts. Ann. Biomed. Eng., 42(6):1305-18, 2014.

Uzarski, J. S.; Van De Walle, A. B. \& McFetridge, P. S. Preimplantation processing of ex vivo-derived vascular biomaterials: effects on peripheral cell adhesion. J. Biomed. Mater. Res. A, 101(1):123-31, 2013.

Vázquez Blanco, M.; Ruda Vega, H.; Guerri-Guttenberg, R. A.; Giuliano, R.; Grana, D. R.; Azzato, F. \& Milei, J. Histopathology and histomorphometry of umbilical cord blood vessels. Findings in normal and high risk pregnancies. Artery Res., 5(2):50-7, 2011.

Velazquez-Gauna, S. E.; Soto-Domínguez, A.; Quiroga-Garza, A.; ReyesHernández, C. G.; Chavez-Reyes, A.; Morales-Avalos, R.; Montes-deOca-Luna, R.; Guzmán-López, S. \& Elizondo-Omaña, R. E. Histomorphometric and immunohistochemical study of early adaptative response of the vascular wall in a termino-terminal microsurgical model of femoral vessels in Wistar rat. Int. J. Morphol., 35(2):479-87, 2017.

World Health Organization (WHO). Global Status Report on Noncommunicable Diseases. Geneva, World Health Organization, 2014. Available from: https://www.who.int/nmh/publications/ncd-statusreport-2014/en/

Yeh, H. S.; Keller, J. T.; Brackett, K. A.; Frank, E. \& Tew, J. M. Jr. Human umbilical artery for microvascular grafting. Experimental study in the rat. J. Neurosurg., 61(4):737-42, 1984.

Zdrahala, R. J. Small caliber vascular grafts. Part I: state of the art. $J$. Biomater. Appl., 10(4):309-29, 1996.

Zilla, P.; Bezuidenhout, D. \& Human, P. Prosthetic vascular grafts: wrong models, wrong questions and no healing. Biomaterials, 28(34):500927, 2007.

Corresponding author:

Alejandro Quiroga Garza

Departamento de Anatomía Humana

Facultad de Medicina

Universidad Autónoma de Nuevo León (UANL)

Ave. Madero y Dr. Aguirre Pequeño S/N

Colonia Mitras Centro

Monterrey N.L.

MÉXICO

Email: dr.aquirogag@gmail.com

Received: 04-09-2018

Accepted: 26-10-2018 